\title{
Studies on IAA Producing Pseudomonas and Serratia spp. Isolated from Agricultural and Garden Soil of Akola Region
}

\author{
R.D. Matre and D.L. Barate* \\ Department of Microbiology, Shri Shivaji College of Arts, Commerce \& Science, \\ Akola (M.S.), India \\ *Corresponding author
}

\section{A B S T R A C T}

\begin{tabular}{l} 
Ke y w o r d s \\
Indole 3-acetic acid \\
(IAA), Serratia \\
spp., Pseudomonas \\
spp. \\
\hline Article Info \\
\hline $\begin{array}{l}\text { Accepted: } \\
\text { 17 June } 2018 \\
\text { Available Online: } \\
\text { 10 July } 2018\end{array}$ \\
\hline
\end{tabular}

\section{Introduction}

In order to meet the challenges of providing food to the ever increasing population, there is an urgent need to boost crop yield. As the rate of population increased, there is also an excessive increase in the usage of chemical fertilizers and pesticides for various purposes. Although achieving the satisfactory results by the application of chemical fertilizers and pesticides, the disadvantages of chemical fertilizers and pesticides are now threatening the agricultural processes, such as pollution of large water resources, destruction of microorganisms, acidity of the soil and reduction in soil fertility (Ahmad et al., 2008). Thus, in the recent years, scientists have diverted their attention towards exploring the potential of beneficial microbes and their use in plant growth promotion for sustainable agriculture.

Plant hormones regulate or influence a range of cellular and physiological process, such as cell division, cell enlargement, bud dormancy, flowering, fruit ripening, seed dormancy, seed germination and leaf abscission. Indole-3acetic acid (IAA) is the main member of the 
auxin family that controls many important physiological processes including cell enlargement and division, tissue differentiation, and responses to light and gravity (Taele et al., 2006). Various microorganisms including bacteria, fungi, and algae are capable of producing physiologically active quantities of auxins, which may exert pronounced effects on plant growth and establishment. Bacteria belonging to the genera Azospirillum, Pseudomonas, Xanthomonas, and Rhizobium as well as Alcaligenes faecalis, Enterobacter cloacae, Acetobacter diazotrophicus and radyrhizobium japon-icum have been shown to produce auxins which help in stimulating plant growth (Patten and Glick, 1996).

The species of genus Pseudomonas are widely distributed in nature and act as plant growthpromoting rhizobacteria by nitrogen fixation, mineral solubilization, as well as transformation of nutrients, production of phytohormones and siderophores, and 1aminocyclopropane-1-carboxylic acid (ACC) deaminase (Lugtenberg and Kamilova, 2009). Although IAA production has been reported in Pseudomonas species, there is not much information on statistical optimization of nutritive conditions for its production (Karnwal, 2009).

The IAA produced by bacteria colonizing the rhizosphere of the plants is proposed to act in conjunction with endogenous IAA in plant to stimulate cell proliferation, elongation, and enhancement of host's uptake of minerals and nutrients from the soil. IAA also serves as a regulating agent for microbial cell differentiation (Suzuki and Oyaizu, 2003; Leveau and Lindow, 2005). Tryptophan is believed to be the primary precursor for the formation of IAA in plants and microorganism (Monteiro et al., 1988). Different bacterial pathways to synthesize IAA have been identified and a high degree of similarity between IAA biosynthesis pathways in plants and bacteria was observed (Spaepen et al., 2007).

Indole -3-acetic acid (IAA) is the common natural auxin that shows all auxin doing actions and extensively affects plant's physiology. Thus the present study aimed to isolate the Pseudomonas spp and Serratia spp from soil samples of Akola region and check the effect of various parameters on its production.

\section{Materials and Methods}

\section{Collection of soil samples}

The soil samples were collected from different areas of Akola region. The samples were collected in sterile plastic bag and brought to the laboratory for further work.

\section{Isolation and identification of Pseudomonas and Serratia spp.}

The soil samples were inoculated on Pseudomonas isolation agar and Nutrient agar the colonies showing similarity with the two were selected and purified and maintained on nutrient agar slant. Further the identification was done by cultural morphological and morphological and biochemical characteristics.

\section{Determination of IAA production by isolates}

The isolates were inoculated separately in the nutrient broth supplemented separately in the nutrient broth supplemented with Ltryptophan and incubated for 96 hrs. After 24 hours interval $10 \mathrm{ml}$ amount of media removed and centrifuged at $5000 \mathrm{rpm}$ for 15 minutes. The $1 \mathrm{ml}$ of supernatant was mixed with $2 \mathrm{ml}$ of Salkowski's reagent $(50 \mathrm{ml}$ of $35 \%$ perchloric acid and $1 \mathrm{ml}$ of $0.5 \mathrm{M} \mathrm{FeCl}_{3}$ 
solution) and 2 drops of orthophosphoric acid. The mixture was incubated in dark for $1 \mathrm{hr}$. Red colour development was recorded with spectrophotometer at $530 \mathrm{~nm}$.

Preparation of standard curve for IAA estimation

Standard curve was prepared by taking 0.1 , $0.2,0.3,0.4,0.5,0.6,0.7,0.8,0.9$ and $1.00 \mathrm{ml}$ of standard IAA solution in test tubes.

The volume was made to $2 \mathrm{ml}$ with distilled water and then $4 \mathrm{ml}$ of Salkowaski reagent was added and tubes were incubated for 25 minutes at room temperature and optical density was measured at $530 \mathrm{~nm}$. Standard curve was prepared by plotting absorbance at $530 \mathrm{~nm}$ against concentration of IAA solution.

\section{Effect of temperature on IAA production}

Effect of temperature on IAA production was studied by inoculating the culture in the production media and incubating at different temperatures as room temp, $37^{\circ} \mathrm{C}, 40^{\circ} \mathrm{C}$. The IAA production was calculated as per previously described.

\section{Effect of pH on IAA production}

The production media was adjusted for $\mathrm{pH} 3$, 5,7 and 9 by addition of $1 \mathrm{~N} \mathrm{HCl}$ and $1 \mathrm{~N}$ $\mathrm{NaOH}$. The media were then inoculated with cultures, incubated and IAA produced was determined spectrophotometrically at $530 \mathrm{~nm}$ as previously described.

\section{Effect of carbon sources on IAA production}

The production media was supplemented with $1 \%$ of sugar like glucose, sucrose and mannitol were then inoculated after autoclaving with cultures incubated and IAA was estimated at $530 \mathrm{~nm}$ by spectrophotometer as described.

\section{Effect of L- tryptophan concentration on IAA production}

Production media was supplemented with different concentration of L- tryptophan as $0.05 \%, 1 \%, 2 \%$ and $3 \%$. It was inoculated with cultures after autoclaving and after incubation IAA was determined at $530 \mathrm{~nm}$ by spectrophotometer.

\section{Results and Discussion}

In the present study a total of 25 bacterial isolates were obtained from the soil samples. Primarily on the basis of colour on the media colonies were selected and coded as $\mathrm{S}$ for Serratia and P for Pseudomonas. The isolates were then identified by cultural, morphological and biochemical characteristics by standard conventional methods.

In the isolates 10 Serratia spp and 15 Pseudomonas spp found IAA producers by using Salkowski reagent. The intensity of pink colour development at $530 \mathrm{~nm}$ after addition of reagent was noted for each isolate. The results were recorded for IAA production after each $24 \mathrm{hrs}$. It was found that IAA production was maximum at $72 \mathrm{hrs}$ of incubation time (Fig. 1 and 2). The two isolates $\mathrm{S}_{7}$ and $\mathrm{P}_{6}$ each from Serratia spp and Pseudomonas spp were selected for further study as both the isolates showed maximum IAA production amongst all isolates. This is in agreement with other studies who also supported the production of IAA by Pseudomonas and Serratia spp. (Karnwal, 2009; Malik and Sindhu, 2011; Kamble and Galerao, 2015; Bharucha et al., 2013; Reetha et al., 2014; Serepa et al., 2015; Lwin et al., 2012).

The quantitative estimation of IAA needs the standard graph for which the known concentrations of standard IAA procured from Himedia were prepared and estimated with spectrophotometer at $530 \mathrm{~nm}$ (Fig. 3). 
In the study effect of various parameters like temperature, $\mathrm{pH}$, carbon sources and tryptophan concentration was studied on IAA production of $\mathrm{S}_{7}$ and $\mathrm{P}_{6}$.

The effect of temperature studied shows that IAA production was maximum for isolates $\mathrm{P}_{6}$ (Pseudomonas spp.) at $37^{\circ} \mathrm{C}$ which was 59 $\mu \mathrm{g} / \mathrm{ml}$ after $72 \mathrm{hrs}$ of incubation. At room temperature $\mathrm{P}_{6}$ showed $55 \mu \mathrm{g} / \mathrm{ml}$ IAA production while at $40^{\circ} \mathrm{C}$ it was $52 \mu \mathrm{g} / \mathrm{ml}$. In a similar way IAA production at various temperature for isolate $\mathrm{S}_{7}$ (Serratia spp) showed that IAA was produced maximally at $40^{\circ} \mathrm{C}$ temperature which was $92 \mathrm{ug} / \mathrm{ml}$. At room temperature it was $75 \mu \mathrm{g} / \mathrm{ml}$ and at $37^{\circ} \mathrm{C}$ it was $68 \mu \mathrm{g} / \mathrm{ml}$ (Fig. 4).

According to Sudha et al., (2017) also $37^{\circ} \mathrm{C}$ temperature was optimum for IAA production for Rhizobium and Bacillus spp. Bharucha et al., (2013) studied IAA production at $30^{\circ} \mathrm{C}$ from Pseudomonas putida. Sachdev et al., (2009) reported. Maximum IAA production at $37^{\circ} \mathrm{C}$ after $72 \mathrm{hrs}$ of incubation. Kamble and Galerao (2015) reported very few cultures of Pseudomonas spp producing IAA at $45^{\circ} \mathrm{C}$.
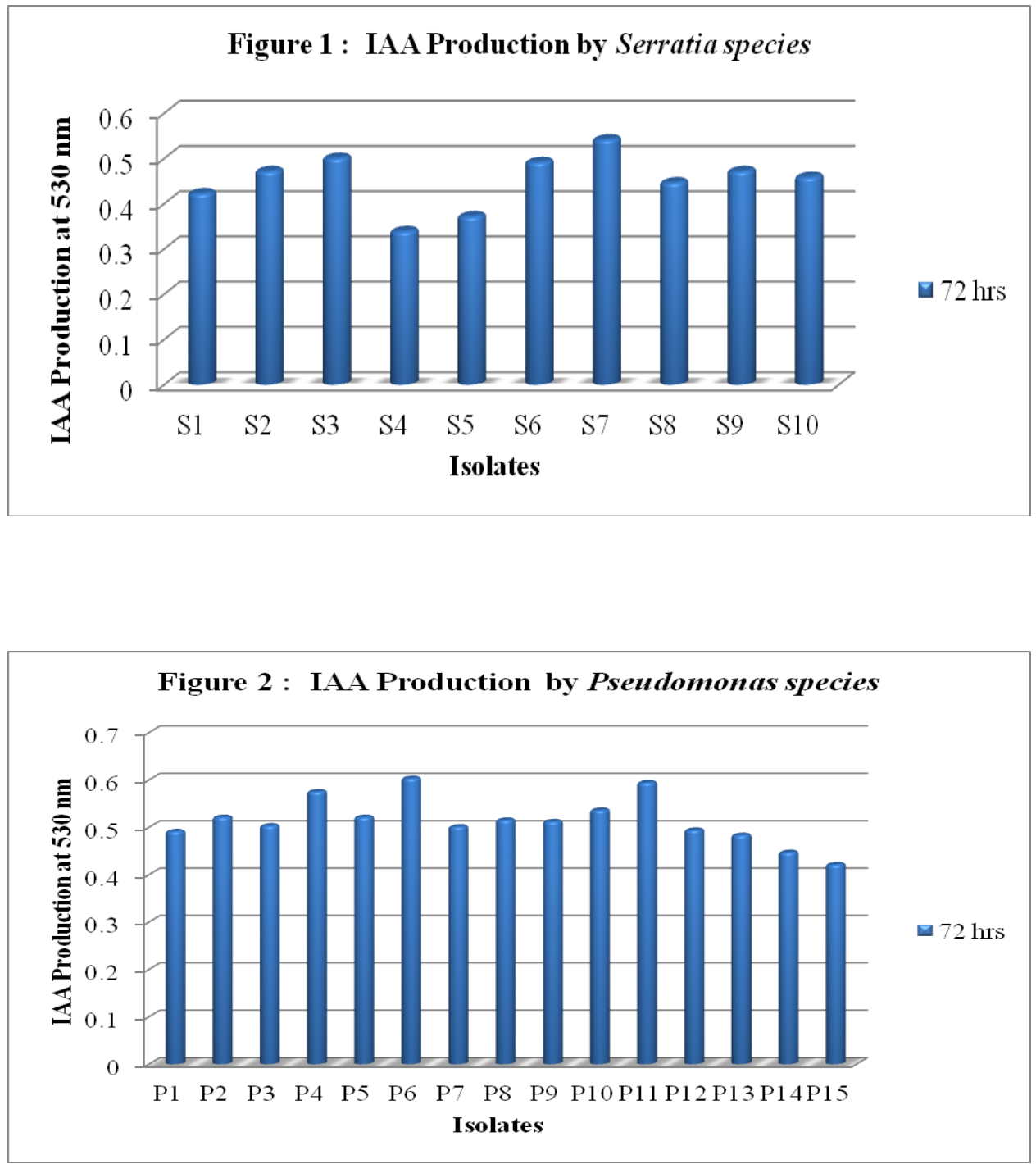

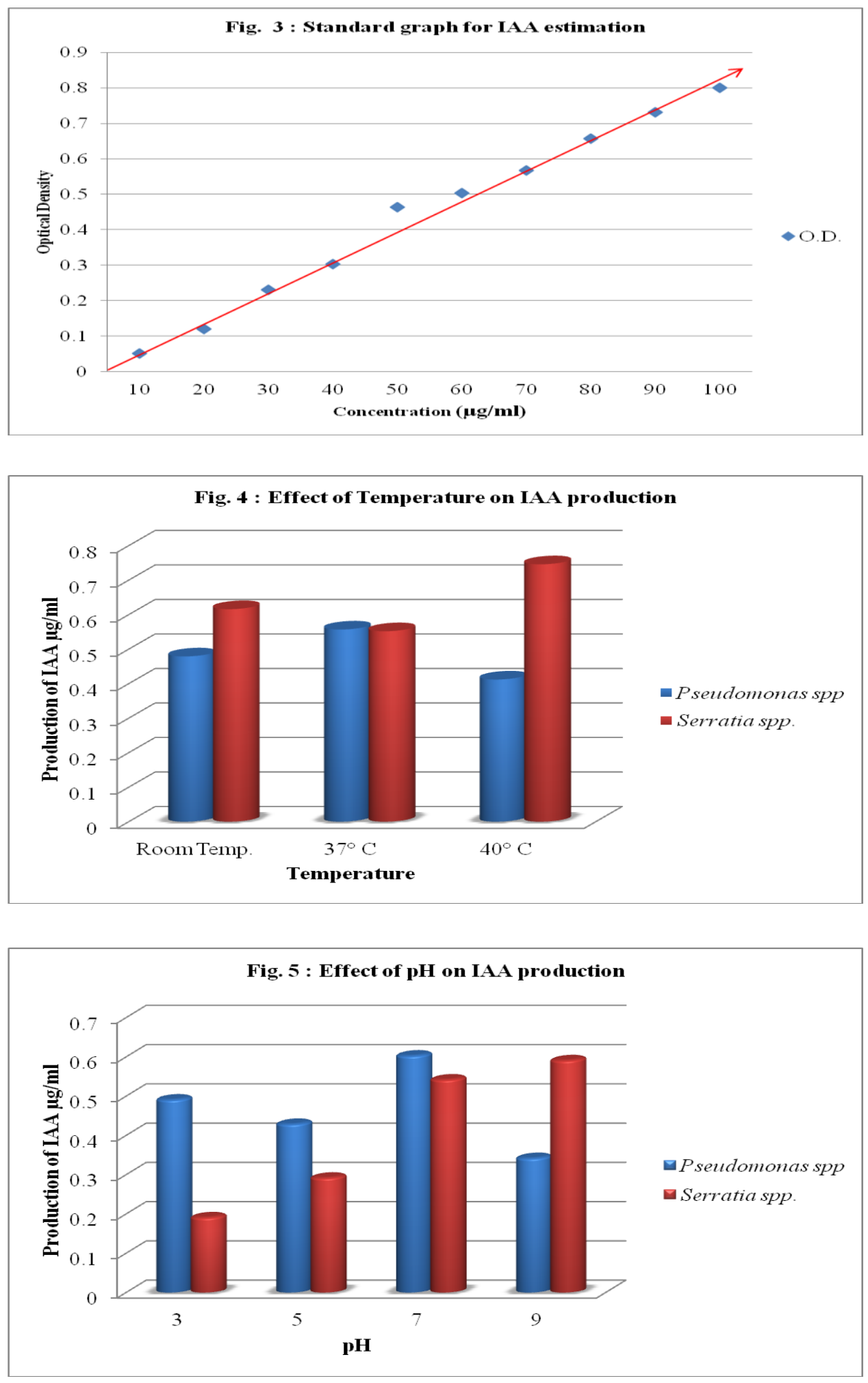
Int.J.Curr.Microbiol.App.Sci (2018) 7(7): 2492-2501
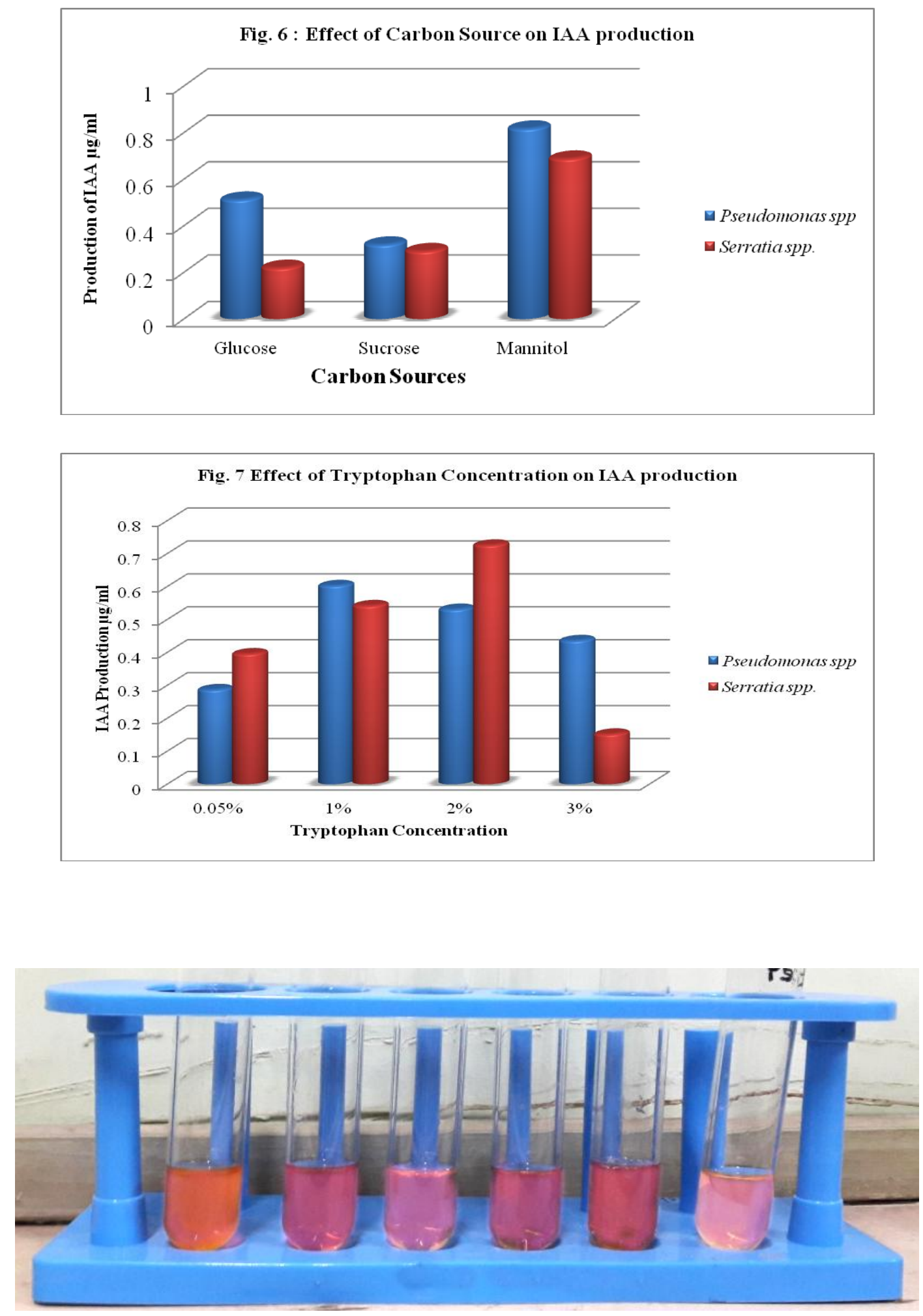

IAA Produced by Isolates 
In the study pH 3, 5, $7 \& 9$ were adjusted with the production medium and its effect on IAA production was studied (Fig. 5). It was found that P6 showed maximum IAA production 74 $\mu \mathrm{g} / \mathrm{ml}$ at $\mathrm{pH} 7$ while $\mathrm{S} 7$ showed maximum IAA production $42 \mu \mathrm{g} / \mathrm{ml}$ at $\mathrm{pH} 9$, after $72 \mathrm{hrs}$ of incubation our results are in correlation with the Barucha et al., (2013) who also reported maximum IAA production at $\mathrm{pH} 7.5$ for Pseudomonas spp. While it is similar to the reports of Kamble and Galerao (2015), who also reported maximum IAA production at $\mathrm{pH}$ 7. Mohite (2013) reported $\mathrm{pH} 9$ was optimum for the IAA production for one of the strain.

Effect of three different carbon sources like glucose, sucrose and mannitol at $1 \%$ concentration was also studied. Mannitol was found to be the best carbon source which gave maximum production of IAA than glucose and sucrose (Fig. 6). This is in agreement with the Sridevi et al., (2008) who also revealed that mannitol and glutamic acid were best promotor for IAA production. Shilts et al., (2005) and Mohite (2013) also reported mannitol as best carbon source. Bharucha et al., (2013) reported source is the best carbon source for IAA production which is concordance with the present study.

L-tryptophan is considered as a precursor of IAA production because its addition to medium increase IAA production (Ahmad et $a l .$, 2005). To check this effect, different concentrations of L-tryptophan between $0.05 \%-3 \%$ were added to the medium for IAA production (Fig. 7). It was found that with increase in tryptophan concentration IAA production was also increased. For isolate $\mathrm{P}_{6} \quad 1 \%$ tryptophan concentration showed highest production of $74 \mu \mathrm{g} / \mathrm{ml}$ for IAA than other concentrations. While for isolate $\mathrm{S}_{7}$ the optimum concentration of tryptophan was recorded $2 \%$ at which 89 $\mu \mathrm{g} / \mathrm{ml}$ of IAA was found to be produced.
Mohite (2013) also reported $0.1 \%, 1.5 \%$ and $0.05 \%$ showed maximum IAA production while Bharucha et al., (2013) reported 0.2 as optimum concentration of tryptophan for IAA production. Khalid et al., (2004) showed variable amount of auxins produced by the rhizobacteria in vitro and amendment of the culture media with L-tryptophan stimulates IAA biosynthesis

In conclusion, the isolate P6 (Pseudomonas spp) \& S7 (Serratia spp) showed potential of IAA production. Thus the isolates P6 and S7 would be beneficial in agricultural biotechnology in increasing crop production. Studies on optimization suggest that - IAA production was maximum at $40^{\circ} \mathrm{C}$ for $\mathrm{S} 7$ and $37^{\circ} \mathrm{C}$ for $\mathrm{P} 6$ at $72 \mathrm{hrs}$ of incuation at $\mathrm{pH} 9$ and 7 respectively. The Mannitol was found to be best carbon source for IAA production. The $1 \%$ and $2 \%$ tryptophan was found to be optimum for maximum IAA production for P6 and S7 respectively.

\section{References}

Adams BJ, Fodor A, Koppenhöfer HS, Stackebrandt E, Stock, SP, Klein MG (2006). Reprint of biodiversity and systematics of nematode- bacterium entomopathogens. Biol. Control 38: 4-21.

Ali B, Sabri AN, Ljung K, Hasnain S. (2009) Auxin production by plant associated bacteria: impact on endogenous IAA content and growth of Triticum aestivum L, Lett. Appl. Microbiol., 48(5):542-547.

Anjum M. A., M. R. Sajjad, N. Akhtar, M. A. Qureshi, A. Iqbal, A. R. Jami, and M. U. Hasan, (2007). Response of cotton to plant growth promoting rhizobacteria (PGPR) inoculation under different levels of nitrogen. Journal of Agricultural Research, 45 (2): 135 - 143,.

Apine OA, Jadhav JP (2011). Optimization of medium for indole-3-acetic acid production using Pantoea agglomerans strain PVM, J. Appl. Microbiol., 110(5): $1235-1244$. 
Arkhipova TN, Veselov SU, Melentiev AI, Martynenko EV, Kudoyarova GR. (2005). Ability of bacterium Bacillus subtilis to produce cytokinins and to influence the growth and endogenous hormone content of lettuce plants. Plant and Soil. 272: 201-209.

Arshad M, Frankenberger WT (1991). Microbial production of plant hormones. Plant Soil 133: 1-8.

Arshad M, Frankenberger WT. (1992). Microbial production of plant growth regulators. In: Metting FB Jr (eds). Soil Microbial Ecology, Marcel Dekker Inc., New York., pp. 307-347

Asghar HN, Zahir ZA, Arshad M, Khalik A. (2002) Relationship between in vitro production of auxins by rhizobacteria and their growth-promoting activities in Brassica juncea L. Biol. Fertil. Soils, 35: 231-237.

Balaji N, Lavanya SS, Muthamizhselvi S, Tamilarasan K (2012). Optimization of fermentation conditions for indole acetic acid production by Pseudomonas species, Int. J. Adv. Biotechnol Res., 3(4): $797-$ 803

Barea JM, Brown ME (1974) Effects on plant growth by Azotobacter paspali related to synthesis of plant growth regulating substances J. Appl. Bacteriol. 37: 583593.

Bharucha U, Kamlesh P. (2013). Optimization of indole acetic acid production by Pseudomonas putida UB1 and its effect as plant growth-promoting rhizobacteria on mustard (Brassica nigra), Agric. Res. 2 (3):215-221.

Boemare NE, Akhurst RJ, Mourant RG (1993). DNA relatedness between Xenorhabdus sp. (Enterobacteriaceae), symbiotic bacteria of entomopathogenic nematodes, and a proposal to transfer Xenorhabdus luminescens to a new genus, Photorhabdus gen. nov. Int. J. Syst. Bacteriol. 4: 249 - 255.

Brown ME (1972). Plant growth substances produced by microorganisms of soil and rhizosphere. J. Appl. Bacteriol., 43: 443 451.

Carreno-Lopez R, Campos-Reales N, Elmerich C,
Baca BE. (2000). Physiological evidence for differently regulated tryptophandependent pathways for indole-3-acetic acid synthesis in Azospirillum brasilense. Mol. Gen. Genet. 264 (4): 521 - 530.

Caumette P, Matheron R, Raymond N, Relexans JC. (1994). Microbial mats in the hypersaline ponds of Mediterranean salterns (Salins-de-Giraud, France). FEMS Microbiol. Ecol., 13: 273-286.

Chaiharn M, Lumyong S. (2011). Screening and optimization of indole-3-acetic acid production and phosphate solubilization from rhizobacteria aimed at improving plant growth, Curr Microbiol., 62(1): 173-181.

Datta C, Basu P. (2000). Indole acetic acid production by a Rhizobium species from root nodules of a leguminous shrub Cajanus cojan. Microbiol. Res. 155: 123 $-127$.

Davies P.J. (1995). Plant Hormones: Physiology, Biochemistry, and Molecular Biology. Kluwer Academic Publishers, Netherlands,.

Dillman AR, Chaston JM, Adams BJ, Ciche TA, Goodrich-Blair H, Stock SP, Sternberg PW (2012). An entomopathogenic nematode by any other name. Public Library of Science Pathogens, 8: e1002527.

Dimkpa CO, Zeng J, McLean JE, Britt DW, Zhan $\mathrm{J}$, Anderson AJ, (2012). Production of indole-3- acetic acid via the indole-3acetamide pathway in the plant-beneficial bacterium Pseudomonas chlororaphis O6 is inhibited by $\mathrm{ZnO}$ nanoparticles but enhanced by $\mathrm{CuO}$ nanoparticles, Appl. Environ. Microbiol., 78(5): 1404 - 1410.

Forni C, Riou J, Grilli CM, Tel-Or E, (1992). Indole-3- acetic acid (IAA) production by Arthrobacter species isolated from Azolla, J. Gen. Microbiol., 138(2): 377 381.

Freitas JR, Banerjee MR, Germida JJ. (1997). Phosphate solubilizing rhizobacteria enhance the growth and yield but not phosphorus uptake of canola (Brassica napus). Biol. Fertil. Soils. 24: $358-364$.

Gaskins MH, Albrecht SL, Hubble DH. Rhizosphere bacteria and their use to 
increase productivity: A Review. Agri. Eco. Environ., Vol. 12, 1985, pp. 99-116.

Glick B.R. (1995). The enhancement of plant growth by free living bacteria. Canadian Journal of Microbiology, 41: 109 - 114.

Horemans S, Vlassak K. (1985). Production of indol-3-acetic acid by Azospirillum brasilense. In: W. Klingmuller (Ed.), Azospirillum III: genetics, physiology, Ecology Springer- Verlag, Berlin.

Hussien AAE, Hanan AE (2008). Xenoprotec: Antimicrobial Agent Derived from Xenorhabdus indica. J. Agric. Environ. Sci. 2:568-576. Jukes TH, Cantor CR (1969). Evolution of protein molecules. New York: Academic Press, pp. 21-132.

Joo G J, Kim YM, Kim JT, Rhee IK, Kim JH, Lee IJ. (2005). Gibberellins-producing rhizobacteria increase endogenous gibberellins content and promote growth of red peppers. J. Microbiol., 43: $510-$ 515.

Karnwal, A. (2009). Production of indole acetic acid by fluorescent Pseudomonas in the presence of L-tryptophan and rice root exudates. J. Plant Pathol. 91(1): 61 - 63.

Kelen M., E. Çubuk Demiralay ,S. Şen, and G. Özkan (2004). "Separation of abscisic acid, indole - 3 - acetic acid, gibberellic acid in 99R (Vitis berlandierix Vitis rupestris) and rose oil (Rosa damascene Mill.) by reverse phase liquid chromatography. Turkish Journal of Chemistry, 28 (5): 603 - 610,

Khamna S, Yokota A, Peberdy JF, Lumyong S, (2010). Indole-3-acetic acid production by Streptomyces sp. isolated from some Thai medicinal plant rhizosphere soils, Eur. Asia J. Biosci., 4(4): 23 - 32

Khamna S, Yokota A, Peberdy JF, Lumyong S, (2010). Indole-3-acetic acid production by Streptomyces sp. isolated from some Thai medicinal plant rhizosphere soils, Eur. Asia J. Biosci., 4(4): 23-32

Kloepper J.W., Leong J., Teintze M., Schroth M.N. (1980). Enhanced plant growth by siderophores produced by plant growth promoting rhizobacteria. Nature 286: 885- 886.

Koga J, Adachi T, Hidaka H. (1991). Molecular cloning of the gene for indolepyruvate..
Lee M, Breckenridge C, Knowles R (1970). Effect of some culture conditions on the production of indole- 3-acetic acid and gibberellin like substances by Azotobacter vinelandii. Can. J. Microbiol. 16: 13251330

Leveau, J.H.J., Lindow, S.E.(2005). Utilization of the plant hormone indole-3-acetic acid for growth by Pseudomonas putida strain 1290. Appl. Environ. Microbiol. 71: 2365 $-2371$.

Liu Q, Mracek Z, Zhang L, Puza V, Dong L (2012). Re-description of Oscheius chongmingensis (Zhang et al., 2008) (Nematoda: Rhabditidae) and its entomopathogenicity. Nematology 14: 139 - 149.

Lugtenberg, B., Kamilova, F. (2009). Plant growth promoting rhizobacteria. Ann Rev Microbiol. 63, 541-556.

Lynch JM. (1985). Origin, nature and biological activity of Aliphatic substances and growth hormones found in soil. In Vaughan D, Malcom RD (Eds). Soil Organic Matter and Biological Activity. Martinus Nijhoff W Junk Publishers. Dordrecht, Boston, Lancaster, pp. 151174.

Moore TS (1989). Biochemistry and physiology of plant 2nd edn. New York: SpringerVerlag Inc., 285.

Muller M, Deigele C, Ziegler H (1989). Hormonal interactions in the rhizospheres of maize (Zea mays L.) and their effect on plant development. $Z \quad P$, flanzenernahar. Bodenkd,, 152: 247 - 254.

Munees A.and S. K. Mohammad (2001). Functional aspect of plant growth promoting rhizobacteria, Insight Microbiology, 1: 39 - 54,

Napier RM, Venis MA (1995). Auxin action and auxin-binding proteins. New Phytol. 129: $167-201$.

Normanly J (1997). Auxin metabolism. Physiol. Plantarum 100: 431- 442.

Okon Y. and C .A. Labandera - Gonzalez, (1994). "Agronomic applications of Azospirillum," in Improving Plant Productivity with Rhizosphere Bacteria, Australia: Commonwealth Scientific and Industrial Research Organization, 
Ona O, Van Impe J, Prinsen E, Vanderleyden J, (2005). Growth and indole-3-acetic acid biosynthesis of Azospirillum brasilense Sp245 is environmentally controlled, FEMS Microbiol. Lett.; 246(1):125-132.

Oren A, Seckbach J. (2001). Oxygenic phothosynthetic microorganisms in extreme environments. Nova Hedwigia. 123: 13-31.

Patten C., Glick B.R., (1996). Bacterial biosynthesis of indole-3- acetic acid. Canadian Journal of Microbiology, 42: $207-220$.

Pichu, R. (1989). "Free- living bacterial inoculate for enhancing crop productivity. Trends in Biotechnology, 7: 39 - 44,

Sarwar M, Frankenberger WT (1994). Tryptophan dependent biosynthesis of auxins in soil. Plant and Soil, 160: 97-104.

Scott TK (1972). Auxins and roots. Annu. Rev. Plant Physiol. 23: 235- 258.

Spaepen, S., Vanderleyden, J., Remans, R. (2007). Indole-3-acetic acid in microbial and Microorganism-plant signaling. FEMS Microbiol. Rev. 31(4): 425- 448.

Teale, W.D., Paponov, I.A., Palme, K. (2006). Auxin in action: signaling, transport and the control of plant growth and development. Mol. Cell Biol. 7: 847 859.

Tien T.M., Gaskins M.H., Hubbell D.H., (1979). Plant growth substances produced by Azospirillum brasilense and their effect on the growth of pearl millet (Pennisetum americanum L.). Applied and Environmental Microbiology. 37: 10161024.

Wang H, Liu Y, Dong H, Qin L, Cong B, Li T (2011). Antibiotic activity of bacterial isolates associated with entomopathogenic nematodes. Afr. $J$. Microbiol. Res., 5: 5039-5045.

Wang Y, Fang X, An F, Wang G, Zhang X (2011). Improvement of antibiotic activity of Xenorhabdus bovienii by medium optimization using response surface methodology. Microb. Cell Fact., 10: 115.

Wright ES, Yilmaz LS, Noguera DR (2012). Decipher, a search-based approach to chimera identification for 16S rRNA sequences. Appl. Environ. Microbiol. 78: 717-725.

Zhao Y. (2010). Auxin biosynthesis and its role in plant development. Annu. Rev. Plant Biol. 61: 49-64.

\section{How to cite this article:}

Matre, R.D. and Barate, D.L. 2018. Studies on IAA Producing Pseudomonas and Serratia spp. Isolated from Agricultural and Garden Soil of Akola Region Int.J.Curr.Microbiol.App.Sci. 7(07): 2492-2501. doi: https://doi.org/10.20546/ijcmas.2018.707.292 